\title{
The Effects of Diet and Stool Composition on the Net External Acid Balance of Normal Subjects*
}

\author{
Edward J. Lennon, Jacob Lemann, Jr., $†$ and John R. Litzow $\ddagger$ \\ (From the Department of Internal Medicine and the Clinical Research Center, Marquette \\ University School of Medicine and Milwaukee County Hospital, Milwaukee, Wisc.)
}

In 1961, Relman, Lennon, and Lemann (1) reported an experimental technique that permitted independent measurement of the net production of fixed endogenous acid. When compared with the simultaneous rate of renal acid excretion, external acid balance could be calculated. This technique depended upon the use of a liquid formula diet prepared so that it contained no potential sources of alkali. The only possible sources of fixed acid production in subjects eating the diet were from the oxidation of organic sulfur in the diet to inorganic sulfate and from the urinary losses of organic acid anions generated as free organic acids during the combustion of neutral foodstuffs. Hence, production of fixed endogenous acid could be measured as the sum of urinary inorganic sulfate and organic acid salts.

Although this diet greatly simplified the measurement of endogenous production of fixed acid, its limited palatability and low calcium content were unsuitable for the prolonged studies that we wished to carry out to examine the relationship between acid balance and calcium balance.

The present studies were undertaken to see if a more general approach to the measurement of endogenous acid production could be devised that would be applicable to whole food diets. Three different types of diets were used, two consisting of whole foods and one a new liquid formula diet, each of which contained different amounts of po-

* Submitted for publication April 11, 1966; accepted July 7, 1966.

This investigation was supported in part by grants RO1 AM 08924 and 5 MO1 FR00058 from the U. S. Public Health Service.

† Address requests for reprints to Dr. Jacob Lemann, Jr., Dept. of Medicine, Milwaukee County General Hospital, 8700 West Wisconsin Avenue, Milwaukee, Wisc., 53226.

$\$$ Trainee in the Dept. of Medicine, Marquette University School of Medicine. Supported by U. S. Public Health Service training grant 2 T1 AM5023 (e). tential alkali. With these diets, no correlation between the sum of urinary inorganic sulfate plus organic acid salts and renal acid excretion was found. However, when gains of potential alkali from the diet and losses of potential alkali in the stool were included in the calculation of total effective acid production, good correlation between acid production and renal acid excretion was found.

\section{Methods}

Sixteen metabolic balance studies were carried out on 14 healthy men in the Clinical Research Center, Marquette University School of Medicine.

Each subject's diet was constant throughout his balance study. Three general types of diets were used. Two were whole food diets, and one was a liquid formula. The type A whole food diets were designed to contain more inorganic cations than inorganic anions, as in average American diets. The type $B$ diets were designed to provide more inorganic anions than inorganic cations through unusual intakes of phosphorus in egg yolk. Representative sample menus of type A and type B diets are shown in Table I. In the liquid formula diet used, a purified soy phosphoprotein ${ }^{1}$ served as the sole nitrogen source, and inorganic cations and anions were approximately equal. The protein contained very small quantities of inorganic electrolytes except for phosphorus, as shown in Table II. As previously described (2), we added equimolar quantities of $\mathrm{Ca}(\mathrm{OH})_{2}$ and $\mathrm{Mg}(\mathrm{OH})_{2}$ in amounts theoretically sufficient to titrate all of the

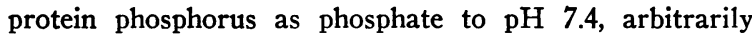
assuming that no other cations were present in the protein

Each subject was allowed 3 to 6 days to adjust to his constant diet before observations began. Thereafter, each metabolic period lasted 6 days. The number of subjects studied on each type of diet and the number of metabolic periods observed for each subjects were as follows: whole food type A, 7 subjects, 2 to 4 periods each; whole food type B, 2 subjects for 2 periods each; and the liquid formula diet, 7 subjects for 1 period each.

Collection of specimens. Venous blood for measurement of carbon dioxide content and electrolytes was drawn without stasis into syringes rinsed with mineral

\footnotetext{
1 Edi-Pro-A, Ralston Purina Co., St. Louis, Mo.
} 
TABLE I

Representative menus of whole food diets

\begin{tabular}{|c|c|c|c|}
\hline \multicolumn{2}{|l|}{ Type A } & \multicolumn{2}{|l|}{ Type B } \\
\hline $\begin{array}{l}\text { Calories } \\
\text { Protein } \\
\text { Fat } \\
\text { Carbohydrate }\end{array}$ & $\begin{array}{r}2,620 \\
78 \mathrm{~g} \\
140 \mathrm{~g} \\
262 \mathrm{~g}\end{array}$ & $\begin{array}{l}\text { Calories } \\
\text { Protein } \\
\text { Fat } \\
\text { Carbohydrate }\end{array}$ & $\begin{array}{r}2,210 \\
79 \mathrm{~g} \\
118 \mathrm{~g} \\
208 \mathrm{~g}\end{array}$ \\
\hline $\begin{array}{l}\text { Breakfast } \\
\text { Orange juice } \\
\text { Cereal* } \\
\text { Egg (whole) } \\
\text { Toast* } \\
\text { Butter* } \\
\text { Milk } \\
\text { Coffee } \\
\text { Sugar }\end{array}$ & $\begin{array}{r}g \\
100 \\
15 \\
50 \\
50 \\
15 \\
100 \\
200 \\
15\end{array}$ & $\begin{array}{l}\text { Grape juice } \\
\text { Cereal* } \\
\text { Egg (yolk) } \\
\text { Toast* } \\
\text { Butter* } \\
\text { Milk } \\
\text { Coffee } \\
\text { Sugar }\end{array}$ & $\begin{array}{r}g \\
50 \\
20 \\
125 \\
25 \\
15 \\
100 \\
100 \\
15\end{array}$ \\
\hline $\begin{array}{l}\text { Lunch } \\
\text { Meat (beef) } \\
\text { Potato or } \\
\text { substitute } \\
\text { Vegetable* } \\
\text { Fruit } \\
\text { Bread* } \\
\text { Butter* } \\
\text { Milk } \\
\text { Coffee } \\
\text { Sugar }\end{array}$ & $\begin{array}{r}90 \\
\\
80 \\
80 \\
100 \\
25 \\
20 \\
240 \\
200 \\
5\end{array}$ & $\begin{array}{l}\text { Meat (turkey) } \\
\text { Noodles } \\
\text { Vegetable* } \\
\text { Fruit } \\
\text { Bread* } \\
\text { Butter* } \\
\text { Milk } \\
\text { Coffee } \\
\text { Sugar }\end{array}$ & $\begin{array}{r}90 \\
\\
100 \\
80 \\
100 \\
25 \\
20 \\
10 \\
100 \\
5\end{array}$ \\
\hline $\begin{array}{l}\text { Supper } \\
\text { Meat (turkey) } \\
\text { Potato or } \\
\text { substitute } \\
\text { Vegetable* } \\
\text { Fruit } \\
\text { Bread* } \\
\text { Butter* } \\
\text { Milk } \\
\text { Coffee } \\
\text { Sugar }\end{array}$ & $\begin{array}{r}60 \\
80 \\
80 \\
100 \\
25 \\
20 \\
240 \\
200 \\
5\end{array}$ & $\begin{array}{l}\text { Meat (beef) } \\
\text { Rice } \\
\text { Vegetable* } \\
\text { Fruit } \\
\text { Bread* } \\
\text { Butter* } \\
\text { Milk } \\
\text { Coffee } \\
\text { Sugar }\end{array}$ & $\begin{array}{r}60 \\
\\
100 \\
70 \\
100 \\
25 \\
20 \\
10 \\
100 \\
5\end{array}$ \\
\hline $\begin{array}{l}9 \text { p.m. snack } \\
\text { Bread* } \\
\text { Butter* } \\
\text { Fruit }\end{array}$ & $\begin{array}{r}25 \\
10 \\
100\end{array}$ & $\begin{array}{l}\text { Bread* } \\
\text { Butter* } \\
\text { Milk }\end{array}$ & $\begin{array}{l}25 \\
10 \\
80\end{array}$ \\
\hline
\end{tabular}

* Salt-free; constant daily quantities of dry $\mathrm{NaCl}$ were provided.

oil. At the same time, specimens of whole blood for estimation of $\mathrm{pH}$ were drawn into syringes rinsed with heparin and $1 \mathrm{~N}$ sodium fluoride. Twenty-four-hour urine specimens were collected in bottles containing thymol and phenyl mercuric nitrate and a layer of mineral oil and refrigerated during collection. Carmine was administered with breakfast on the morning of the first day of each balance period; it served as a marker to separate stool collections for each period. Stools were collected in stainless steel cans and frozen immediately. All stools for each period were quantitatively transferred to a large blender, brought to a measured volume with distilled water, thoroughly homogenized, and analyzed in triplicate. Whole foods were weighed into a large blender, brought to a measured volume with distilled water, and thoroughly homogenized. Duplicate trays of each subject's constant diet were analyzed on 4 to 6 days of each study. The coefficient of variation for the determination of each diet constituent averaged the following: $\mathrm{Na} \pm 3.6 \%, \mathrm{~K} \pm$ $3.3 \%, \mathrm{Ca} \pm 4.1 \%, \mathrm{Mg} \pm 5.2 \%, \mathrm{Cl} \pm 3.4 \%$, and $\mathrm{P} \pm 3.5 \%$. Samples of the diet and stool homogenates were frozen until analysis.

Analytical methods. Blood and urine $\mathrm{pH}$ were estimated at $37^{\circ} \mathrm{C}$ with a Radiometer $\mathrm{pH}$ meter and Astrup capillary glass electrode. Total $\mathrm{CO}_{2}$ content of serum and urine was measured manometrically with either the Van Slyke-Neill apparatus or the Natelson microgasometer. Chloride in serum, urine, and nitric acid digests of diet and stool homogenates was measured with the Cotlove apparatus. Sodium and potassium in serum, urine, and nitric acid digests of diet and stool homogenates were determined with the Autoanalyzer flame spectrophotometer. Phosphorus in serum, urine, and samples of diet and stool homogenate digested with sulfuric acid and hydrogen peroxide was determined with the Autoanalyzer. Creatinine in serum and urine and ammonium in urine were also measured with the Autoanalyzer. Calcium and magnesium in serum, urine, and samples of diet and stool homogenates ashed at $600^{\circ} \mathrm{C}$ for 8 hours were determined by atomic absorption spectrophotometry. Urinary inorganic sulfate was measured gravimetrically as barium sulfate.

Organic acid salts in urine were measured by the Van Slyke and Palmer method (3) with the following modifications. Phosphate was removed by mechanical shaking for 30 minutes with added $\mathrm{Ca}(\mathrm{OH})_{2}$ powder, and the suspension was filtered. Portions of the filtrate were brought to $\mathrm{pH} 2.7$ at $37^{\circ} \mathrm{C}$ with approximately $1 \mathrm{~N}$ $\mathrm{HCl}$, with a Radiometer $\mathrm{pH}$ meter and automatic titrator. The solution was then titrated with $0.1 \mathrm{~N} \mathrm{NaOH}$ to the original $\mathrm{pH}$ of the urine to estimate organic acid salts. The organic acid salt measurement was corrected for titration of creatinine. In previous studies of acid-base balance $(1,2)$ all organic acids titratable between $\mathrm{pH}$ 2.7 and 7.4 (corrected for creatinine) were considered to represent acid production. This was required because urinary titratable acid was measured by direct titration and included as acid excretion those organic acids titrated between urine $\mathrm{pH}$ and $\mathrm{pH}$ 7.4. Organic acids produced in the body from neutral foods and excreted as the acid in urine have no net effect on acid balance. In the present studies the calculation of titratable acid (see below) does not include the organic acids; therefore, only the organic acid salts are measured as acid production.

TABLE II

Electrolyte content per $100 \mathrm{~g}$ of Edi-Pro-A

\begin{tabular}{ccl}
\hline \hline Electrolyte & & \\
\hline $\mathrm{Na}$ & 1.5 & $m E q$ \\
$\mathrm{~K}$ & 2.3 & $m E q$ \\
$\mathrm{Ca}$ & 3.0 & $m E q$ \\
$\mathrm{Mg}$ & 0.5 & $m E q$ \\
$\mathrm{Cl}$ & 2.3 & $m E q$ \\
$\mathrm{P}$ & 26 & mmoles \\
\hline
\end{tabular}


Calculations. Bicarbonate and carbon dioxide pressure $\left(\mathrm{PCO}_{2}\right)$ in serum and urine were calculated from total $\mathrm{CO}_{2}$ content and $\mathrm{pH}$.

Titratable acid (TA) was calculated because varying concentrations of calcium and ammonium in the urine may lead to spurious overestimation of TA by direct titration (4). Urinary excretion of titratable acid with phosphate $\left(\mathrm{TA}_{\mathbf{P O}}\right)$ was calculated from urinary phosphate and urine $\mathrm{pH}$, assuming $\mathrm{pk}_{\mathbf{2}}{ }^{\prime}=6.8$ for phosphate. Urinary excretion of titratable acid with creatinine ( $T A_{\text {creatinine }}$ ) was calculated from urinary creatinine and urine $\mathrm{pH}$, with $\mathrm{pk}^{\prime}=4.92$ for creatinine. Net acid excretion in the urine was then calculated as: $\left(\mathrm{TA}_{\mathrm{PO} 4}+\mathrm{TA}_{\text {ereatinine }}+\right.$ $\mathrm{NH}_{4}^{+}$) $-\mathrm{HCO}_{3}^{-}$.

Net production of fixed endogenous acid was calculated as the sum of urinary inorganic sulfate + organic acid salts - the difference between diet and stool unmeasured anion content. The unmeasured anion content of diet and stool was taken as $\left(\mathrm{Na}^{+}+\mathrm{K}^{+}+\mathrm{Ca}^{++}+\mathrm{Mg}^{++}\right)-\left[\mathrm{Cl}^{-}+\right.$ $1.8 \mathrm{P}$ (mmoles)]. (See Discussion.)

\section{Results}

We studied all subjects when their serum bicarbonate concentration and blood $\mathrm{pH}$ were normal and stable and body weight was steady.

Table III presents the mean daily urinary inorganic sulfate plus organic acid salt excretion for the subjects eating each type of experimental diet and compares this with the mean urinary net acid excretion. If the differences between urinary inorganic sulfate and organic acid salts minus net acid excretion had been taken as the actual acid balance, shown in the lowest line of Table III as " $\Delta$," small but significant differences from zero would have been found in the subjects fed the liquid diet. Furthermore, on whole food diets of usual composition (type A), an apparent positive acid balance of $+27 \pm 9 \mathrm{mEq}$ per day would have been found, whereas the two subjects eating an unusual diet (type B) would have had an ap-

TABLE III

Urinary sulfate plus organic acid salts compared with urinary net acid excretion

\begin{tabular}{|c|c|c|c|c|}
\hline Type of diet & & $\begin{array}{l}\text { Liquid } \\
\text { formula }\end{array}$ & $\begin{array}{l}\text { Whole food, } \\
\text { type A }\end{array}$ & $\begin{array}{l}\text { Whole } \\
\text { food, } \\
\text { type B }\end{array}$ \\
\hline Number of studies & & 7 & 7 & 2 \\
\hline $\begin{array}{l}\text { Urinary } \mathrm{SO}_{4}^{-}+\text {organic } \\
\text { acid salts }\end{array}$ & $m E q / d a y$ & 64 & 74 & 81 \\
\hline Urinary net acid excretion & $m E q / d a y$ & 70 & 47 & 102 \\
\hline $\begin{array}{l}\Delta \\
\mathrm{p} \dagger\end{array}$ & $\begin{array}{l}m E q / d a y \\
m E q / d a y\end{array}$ & $\begin{array}{l}-6 \pm 5^{*} \\
<0.025\end{array}$ & $\begin{array}{l}+27 \pm 9 * \\
<0.001\end{array}$ & -21 \\
\hline
\end{tabular}

* Mean \pm standard deviation.

$\dagger$ Probability that the mean does not differ from zero.
TABLE IV

Average daily diet compositıon

\begin{tabular}{|c|c|c|c|c|}
\hline \multicolumn{2}{|c|}{ Type of diet } & $\begin{array}{l}\text { Liquid } \\
\text { formula }\end{array}$ & $\begin{array}{l}\text { Whole food, } \\
\text { type A }\end{array}$ & $\begin{array}{l}\text { Whole } \\
\text { food, } \\
\text { type B }\end{array}$ \\
\hline \multicolumn{2}{|c|}{ Number of studies } & 7 & 7 & 2 \\
\hline \multirow{8}{*}{$\begin{array}{l}\mathrm{Na} \\
\mathrm{K} \\
\mathrm{Ca} \\
\mathrm{Mg} \\
\text { Sum of cations } \\
\mathrm{Cl} \\
\mathbf{P} \\
\mathrm{P} \times 1.8 \\
\text { Sum of anions } \\
\text { Cations minus } \\
\text { anions }\end{array}$} & $m E q$ & 123 & 152 & 154 \\
\hline & $m E q$ & 60 & 75 & 40 \\
\hline & $m E \bar{q}$ & 23 & 42 & 27 \\
\hline & $m E q$ & 20 & 22 & 20 \\
\hline & $m E q$ & 226 & 291 & 241 \\
\hline & mmoles & 26 & 39 & 53 \\
\hline & $\begin{array}{l}m E q \\
m E q\end{array}$ & $\begin{array}{r}46 \\
218\end{array}$ & $\begin{array}{r}71 \\
220\end{array}$ & $\begin{array}{r}95 \\
250\end{array}$ \\
\hline & $m E q$ & $+8 \pm 7 *$ & $+71 \pm 20^{*}$ & -9 \\
\hline
\end{tabular}

* Mean \pm standard deviation.

parent negative acid balance of -20 and -21 $\mathrm{mEq}$ per day. Since the subjects had normal stable serum bicarbonate levels and were in a steady state, an actual acid balance of zero would be expected.

The effect of diet composition on acid production is considered in Table IV, which presents the average daily intakes of measured inorganic constituents for the subjects eating each type of diet. The type A diets had the highest inorganic cation content because of a higher content of potassium and calcium. The type $\mathrm{B}$ diets had the highest inorganic anion content because of a higher phosphorus content. If the phosphorus in each diet is assigned a valence of 1.8 (see Discussion), the difference between measured inorganic cations and anions can be taken as an estimate of excess combustible anions, and hence potential alkali in each diet. Thus, as shown in the bottom line of Table IV, the liquid formula contained a small amount of potential alkali, ${ }^{2}$ whereas type A diets contained a large quantity of potential alkali. Type B diets, on the other hand, appeared to contain a small amount of organic cation, which would yield acid if combusted.

Table $\mathrm{V}$ shows the average stool weight and composition for all subjects. In each group, the stool content of sodium and chloride was close to zero, which indicated that the stools were normally formed. In general, the stools were of similar composition. The stool calcium and magnesium content appeared to vary with dietary intake ( $\mathrm{Ta}$ -

2 This occurred because the inorganic cation in the protein had been neglected in calculating the amount of $\mathrm{Ca}(\mathrm{OH})_{2}$ and $\mathrm{Mg}(\mathrm{OH})_{2}$ required to neutralize the protein phosphate groups. 
TABLE $V$

Average daily stool composition

\begin{tabular}{|c|c|c|c|c|}
\hline \multicolumn{2}{|c|}{ Type of diet } & $\begin{array}{l}\text { Liquid } \\
\text { formula }\end{array}$ & $\begin{array}{l}\text { Whole food, } \\
\text { type A }\end{array}$ & $\begin{array}{l}\text { Whole } \\
\text { food, } \\
\text { type B }\end{array}$ \\
\hline \multicolumn{2}{|c|}{ Number of studies } & 7 & 7 & 2 \\
\hline \multirow{9}{*}{$\begin{array}{l}\text { Weight } \\
\mathrm{Na} \\
\mathrm{K} \\
\mathrm{Ca} \\
\mathrm{Mg} \\
\mathrm{Sum} \text { of cations } \\
\mathrm{Cl} \\
\mathrm{P} \\
\mathrm{P} \times 1.8 \\
\text { Sum of anions } \\
\text { Cations minus }\end{array}$} & & 58 & 58 & 82 \\
\hline & $m E q$ & 1 & 1 & 2 \\
\hline & $m E q$ & 5 & 7 & 12 \\
\hline & $m \vec{E} q$ & 22 & 37 & 26 \\
\hline & $m E q$ & 13 & 13 & 11 \\
\hline & $\begin{array}{l}m E q \\
m E q\end{array}$ & $\begin{array}{r}41 \\
0\end{array}$ & $\begin{array}{r}58 \\
1\end{array}$ & $\begin{array}{r}51 \\
1\end{array}$ \\
\hline & mmoles & 14 & 12 & 15 \\
\hline & $\begin{array}{l}m E q \\
m E q\end{array}$ & $\begin{array}{l}25 \\
25\end{array}$ & $\begin{array}{l}21 \\
22\end{array}$ & $\begin{array}{l}27 \\
28\end{array}$ \\
\hline & & & & \\
\hline anions & $m E \boldsymbol{q}$ & $+16 \pm 9 *$ & $+36 \pm 20^{*}$ & +23 \\
\hline
\end{tabular}

$*$ Mean \pm standard deviation.

ble IV), whereas stool phosphorus appeared to be relatively independent of dietary intake and approximately equal in all groups. The stool potassium content was higher in the subjects eating type B diets, who had somewhat bulkier stools. In the bottom line of Table $\mathrm{V}$ the differences between measured cations and anions in the three diets are shown; the valence of phosphorus in the feces was assumed to be 1.8. The stool contained unmeasured anion in all studies, even when the diet contained none.

Table VI presents the constituents of acid production, renal acid excretion, and the mean daily acid balance for each subject when the apparent balance of combustible anions (diet minus stool unmeasured anions) is included in the calculation of total acid production. The acid balance calculated in this way for the subjects on the liquid diet averaged $+2 \pm 1 \mathrm{mEq}$ per day; this was not statistically significant from zero balance $(p>0.50)$. Similarly, the acid balances of subjects on type A diets averaged $-8 \pm 13 \mathrm{mEq}$ per day when diet and stool unmeasured anions were taken into consideration. This also was not significantly different from zero balance $(p>0.10)$.

As shown in the last column of Table VI the mean acid balance calculated in this way for all subjects was $-1 \pm 12 \mathrm{mEq}$ per day, which is not significantly different from zero $(p>0.70)$. It is clear that the correlation between acid production and renal acid excretion is less precise on whole food diets than on the liquid formula, even if gain or loss of combustible anion in the calculation of net acid production is taken into account.

Figure 1 shows the relationship between renal acid excretion and acid production calculated in three ways for the present studies. At the top, acid excretion is compared with the sum of urinary inorganic sulfate and organic acid salts for all subjects. The correlation of this estimate of acid pro-

TABLE VI

The parameters of acid balance

\begin{tabular}{|c|c|c|c|c|c|c|c|c|}
\hline & Patient & $\begin{array}{c}\text { Diet } \\
\text { combustible } \\
\text { anion }\end{array}$ & $\begin{array}{c}\text { Stool } \\
\text { combustible } \\
\text { anion }\end{array}$ & $\begin{array}{c}\text { Urinary } \\
\mathrm{SO}^{-+}+ \\
\mathrm{OA}^{-*}\end{array}$ & $\begin{array}{c}\text { Total } \\
\text { acid } \\
\text { production } \dagger\end{array}$ & $\begin{array}{c}\text { Renal } \\
\text { acid } \\
\text { excretion }\end{array}$ & $\begin{array}{c}\text { Acid } \\
\text { balance }\end{array}$ & Mean acid balance \\
\hline & & & & & $m E q / d a y$ & & & \multirow[b]{3}{*}{$+2 \pm 7(\mathrm{p}>0.5 \mathrm{C}) \ddagger$} \\
\hline Formula diet & $\begin{array}{l}\text { R.S. } \\
\text { E.B. } \\
\text { J.D. } \\
\text { W.K. } \\
\text { J.B. } \\
\text { D.L. } \\
\text { R.P. }\end{array}$ & $\begin{array}{r}10 \\
2 \\
-5 \\
13 \\
12 \\
15 \\
10\end{array}$ & $\begin{array}{r}14 \\
11 \\
14 \\
35 \\
9 \\
14 \\
17\end{array}$ & $\begin{array}{l}61 \\
60 \\
56 \\
84 \\
58 \\
59 \\
67\end{array}$ & $\begin{array}{r}65 \\
69 \\
75 \\
106 \\
55 \\
58 \\
74\end{array}$ & $\begin{array}{l}63 \\
68 \\
71 \\
90 \\
56 \\
66 \\
74\end{array}$ & $\begin{array}{r}+2 \\
+1 \\
+4 \\
+16 \\
-1 \\
-8 \\
0\end{array}$ & \\
\hline Type A diet & $\begin{array}{l}\text { C.S. } \\
\text { R.P. } \\
\text { A.H. } \\
\text { J.P. } \\
\text { B.I. } \\
\text { L.K. } \\
\text { A.S. }\end{array}$ & $\begin{array}{l}88 \\
88 \\
66 \\
53 \\
74 \\
89 \\
38\end{array}$ & $\begin{array}{l}53 \\
52 \\
24 \\
22 \\
29 \\
66 \\
12\end{array}$ & $\begin{array}{r}102 \\
83 \\
63 \\
76 \\
72 \\
73 \\
48\end{array}$ & $\begin{array}{l}67 \\
47 \\
21 \\
45 \\
27 \\
50 \\
22\end{array}$ & $\begin{array}{l}63 \\
52 \\
46 \\
39 \\
54 \\
49 \\
29\end{array}$ & $\begin{array}{r}+4 \\
-5 \\
-25 \\
+6 \\
-27 \\
+1 \\
-7\end{array}$ & \\
\hline $\begin{array}{l}\text { Type B diet } \\
\text { All studies }\end{array}$ & $\begin{array}{l}\text { A.H. } \\
\text { H.C. }\end{array}$ & $\begin{array}{r}-15 \\
-4\end{array}$ & $\begin{array}{l}22 \\
25\end{array}$ & $\begin{array}{l}72 \\
91\end{array}$ & $\begin{array}{l}109 \\
120\end{array}$ & $\begin{array}{r}92 \\
112\end{array}$ & $\begin{array}{r}+17 \\
+8\end{array}$ & $\begin{array}{l}+12 \\
-1 \pm 12(\mathrm{p}>0.70) \ddagger\end{array}$ \\
\hline
\end{tabular}

${ }^{*} \mathrm{OA}^{-}=$organic acid salts.

$\dagger$ (Urinary $\left.\mathrm{SO}_{4}^{-}+\mathrm{OA}^{-}\right)-$(diet combustible anions - stool combustible anions).

$\ddagger$ Probability that the mean is not different from zero. 


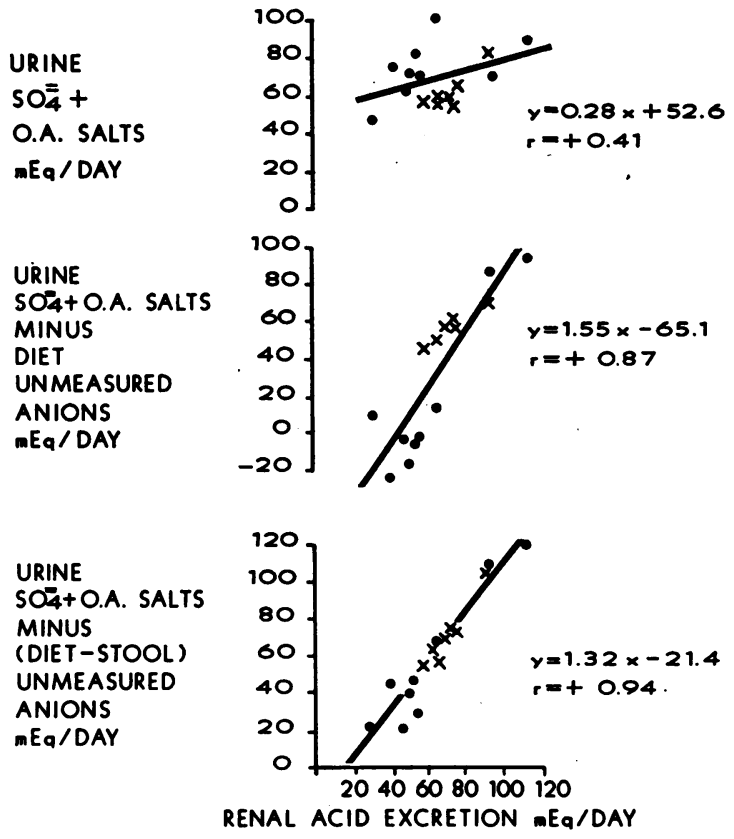

Fig. 1. Correlation of fixed acid production CALCULATED IN THREE WAYS WITH RENAL ACID EXCRETION. The circles indicate subjects eating whole food diets, and the crosses indicate subjects eating a formula diet. $\mathrm{OA}=$ organic acid.

duction and renal acid excretion was poor, as described in Table III, which suggested that other sources of acid, alkali, or both had been omitted in estimating the acid balance. In the middle of Figure 1 , the ingestion of potential alkali in the diet ("unmeasured anions") was subtracted from urinary inorganic sulfate plus organic acid salts, and an estimate of fixed acid production that significantly correlated with renal acid excretion was obtained. In the bottom section of Figure 1, loss of potential alkali in the stool, in addition to gain of potential alkali from the diet, is taken into consideration in the calculation of acid production. The calculation of total effective fixed acid production in this way correlates even more closely with renal acid excretion, which re-emphasizes the necessity of considering loss of potential alkali in the feces. The regression equation for this final relationship states that total effective acid production in milliequivalents per day $=1.32$ (renal acid excretion, $\mathrm{mEq}$ per day) - 21.4. Theoretically, this line should have a slope of one and an intercept of zero. In fact, statistical testing indicated that these data would fit the equation equally well: total effective acid production = renal acid excretion (probability of equally good fit $>0.80$ ).

\section{Discussion}

The metabolic reactions that yield or consume hydrogen ions within the body are summarized in Table VII and have been discussed in detail previously $(1,2,5)$. In these earlier studies the diet contained no excess combustible organic cations or anions, and thus reactions 5 and 6 (Table VII) were eliminated as factors in acid production. However, when whole food diets are eaten, all of the reactions may contribute to effective acid production.

No direct method is available for identifying and quantitating the individual organic cations and anions in food and feces. The net content of organic anion in excess of organic cation, or the converse, can be estimated by comparing the sum of the measured inorganic cations $\left(\mathrm{Na}^{+}+\mathrm{K}^{+}+\mathrm{Ca}^{++}\right.$ $+\mathrm{Mg}^{++}$) with the sum of the measured inorganic anions $\left(\mathrm{Cl}^{-}+\mathrm{P}\right)$. Sulfur is not an anion in foods or feces, since it exists almost entirely in organic compounds in both $(5,6)$.

The valence of phosphorus is obviously important in making an estimate of the quantity of excess organic ions. We have assumed that the mean valence of phosphorus is 1.8 in both natural foods and feces in the absence of precise information about the chemical states of phosphorus in these biological materials. If the actual average valence of phosphorus is significantly different from 1.8, the calculation of excess organic ions will be incorrect.

Assigning phosphorus a valence of 1.8 automatically takes into account reactions 3 and 4 ( $\mathrm{Ta}$ ble VII), since if the two negative changes of the orthophosphate ester shown in the first equation of reaction 3 were covered by hydrogen ions, the organic anion calculation would be reduced by 1.8 , whereas if these changes were covered by potassium, as shown in reaction 4, organic anions would be increased by 0.2 .

By such calculations two of the diets (type A and liquid formula) used in the present studies contained excess organic anions, whereas the third (type B) contained excess organic cations. These are included in the calculation of acid production as sources of potential alkali or acid, respectively. 
TABLE VII

Metabolic reactions that yield or consume hydrogen ions

$\overline{\text { Reaction no. }}$

1. Oxidation of organic sulfur to inorganic sulfate

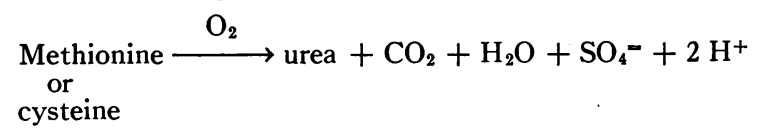

2. Oxidation of neutral foods to organic acids

Glucose $\stackrel{\mathrm{O}_{2}}{\longrightarrow} 2$ lactate $^{-}+2 \mathrm{H}^{+}$

Triglyceride $\stackrel{\mathrm{O}_{2}}{\longrightarrow}$ acetoacetate ${ }^{-}+\mathrm{H}^{+}$

Nucleoprotein $\stackrel{\mathrm{O}_{2}}{\longrightarrow}$ urate $^{-}+2 \mathrm{H}^{+}$

3. Hydrolysis of phosphoester acids

$$
\begin{aligned}
& \mathrm{R}-\mathrm{O}-\underset{\mathrm{O}^{-} \mathrm{H}^{+}}{\stackrel{\mathrm{P}}{\mathrm{O}^{+}} \mathrm{O}^{-}} \mathrm{H}^{+} \frac{\mathrm{H}_{2} \mathrm{O}}{\text { at } \mathrm{pH} 7.4} \mathrm{ROH}+\frac{0.8 \mathrm{HPO}_{4}^{-}}{0.2 \mathrm{H}_{2} \mathrm{PO}_{4}^{-}}+1.8 \mathrm{H}^{+} \\
& \mathrm{R}-\mathrm{O}-\underset{\mathrm{O}^{-} \mathrm{H}^{+}}{\stackrel{\mathrm{O}}{\mathrm{O}}-\mathrm{O}-\mathrm{R}^{\prime}} \stackrel{2 \mathrm{H}_{2} \mathrm{O}}{\text { at pH } 7.4} \mathrm{ROH}+\mathrm{R}^{\prime} \mathrm{OH}+\frac{0.8 \mathrm{HPO}_{4}^{-}}{0.2 \mathrm{H}_{2} \mathrm{PO}_{4}^{-}}+1.8 \mathrm{H}^{+} \\
& \mathrm{R}-\mathrm{O}-\underset{\mathrm{O}^{-} \mathrm{H}^{+}}{\stackrel{\mathrm{P}}{\mathrm{O}}-\mathrm{O}-\mathrm{O}^{-}-\mathrm{H}^{+}} \stackrel{\stackrel{\mathrm{O}}{\mathrm{O}}-\mathrm{O}^{-}}{\mathrm{O}} \mathrm{H}^{+} \frac{2 \mathrm{H}_{2} \mathrm{O}}{\text { at } \mathrm{pH} 7.4} \mathrm{ROH}+\frac{1.6 \mathrm{HPO}_{4}=}{0.4 \mathrm{H}_{2} \mathrm{PO}_{4}^{-}}+3.6 \mathrm{H}^{+}
\end{aligned}
$$

4. Hydrolysis of phosphoester salts

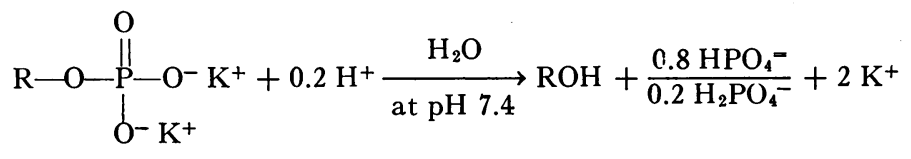

5. Oxidation of organic cations

$$
\mathrm{R}-\mathrm{NH}_{3}+\mathrm{Cl}^{-} \stackrel{\mathrm{O}_{2}}{\longrightarrow} \text { urea }+\mathrm{CO}_{2}+\mathrm{H}_{2} \mathrm{O}+\mathrm{Cl}^{-}+\mathrm{H}^{+}
$$

6. Oxidation of organic anions

$$
\mathrm{R}-\mathrm{COO}^{-} \mathrm{K}^{+}+\mathrm{H}^{+} \stackrel{\mathrm{O}_{2}}{\longrightarrow} \text { urea }+\mathrm{CO}_{2}+\mathrm{H}_{2} \mathrm{O}+\mathrm{K}^{+}
$$

The feces contained organic anions in all studies, and these are also included as loss of potential alkali. Thus, when the dietary gains and fecal losses of organic ions are calculated and the urinary excretion of inorganic sulfate and organic acid salts is measured, an estimate of the net production of fixed acid can be made. Acid production calculated in this way and compared with simultaneously measured renal acid excretion allows determination of net external acid balance.

The nature of the organic ions of the urine and feces suggests that these are largely produced in the body, not derived directly from organic ions of the diet $(6,7)$. Any dietary organic ion that was unmetabolizable or that escaped combustion would be excreted in the urine or feces in the steady state. Because such ions would then be measured both as gain from the diet and loss in the excreta, the calculation of acid balance would not be affected. Consider, for example, the possible fates of ingested sodium hippurate, identified in the diet as potential alkali. If excreted in the urine or 
feces as sodium hippurate, it would be measured again as either endogenous acid production in the urine or potential alkali loss in the stool. In either case the calculation of total acid production would be unaffected. If the hippurate were excreted in the urine or feces as hippuric acid, it would not be measured by our technique. Hence, acid production would be underestimated if the hippurate in the diet were considered potential alkali, but acid excretion from the body would also be underestimated by exactly the same amount and the calculated acid balance would not be altered.

Induced changes in acid balance have previously been related to measured changes in renal acid excretion to allow calculation of a change in acid balance from an assumed zero control balance. If a constant diet is fed, the method described here has the advantage of detecting any changes from the control rate of endogenous acid production in terms of possible variations in the amount of diet sulfur oxidized to sulfate, the loss of organic acid salts in the urine, and the loss of organic anions in the stool.

\section{Summary}

The purpose of this study was to determine whether total effective fixed acid production could be measured in subjects eating whole food diets. We carried out sixteen metabolic balance studies using three types of diets during periods when blood $\mathrm{pH}$ and serum bicarbonate were normal and stable. As in previous studies, urinary inorganic sulfate and organic acid salts were measured as indexes of acid production. In addition, organic anions in excess of organic cations, or the converse, in both the diet and the feces were estimated as the difference between the sum of inorganic cation $\left(\mathrm{Na}^{+}+\mathrm{K}^{+}+\mathrm{Ca}^{++}+\mathrm{Mg}^{++}\right)$and the sum of inorganic anion $\left[\mathrm{Cl}^{-}+1.8 \mathrm{P}\right.$ (mmoles) $]$. Excess organic anions or cations in the diet were assumed to represent potential alkali or acid, respectively. The excess organic anions present in all stools were assumed to represent loss of potential alkali. Total effective acid production was calculated as the sum of urinary inorganic sulfate and organic acid salts minus diet organic anions less fecal organic anions. Good agreement was found when acid production calculated in this way was compared with the quantity of acid simultaneously excreted by the kidney, measured as urinary titratable acid plus ammonium minus bicarbonate.

\section{References}

1. Relman, A: S., E. J. Lennon, and J. Lemann, Jr. Endogenous production of fixed acid and the measurement of the net balance of acid in normal subjects. J. clin. Invest. 1961, 40, 1621.

2. Lennon, E. J., J. Lemann, Jr., and A. S. Relman. The effects of phosphoproteins on acid balance in normal subjects. J. clin. Invest. 1962, 41, 637.

3. Van Slyke, D. D., and W. W. Palmer. Studies of acidosis. XVI. The titration of organic acids in urine. J. biol. Chem. 1920, 41, 567.

4. Lemann, J., Jr., and E. J. Lennon. A potential error in the measurement of urinary titratable acid. J. Lab. clin. Med. 1966, 67, 906.

5. Lemann, J., Jr., and A. S. Relman. The relation of sulfur metabolism to acid-base balance and electrolyte excretion: the effects of pL-methionine in normal man. J. clin. Invest. 1959, 38, 2215.

6. Wrong, O., A. Metcalfe-Gibson, R. B. I. Morrison, S. T. $\mathrm{Ng}$, and A. V. Howard. In vivo dialysis of faeces as a method of stool analysis. I. Technique and results in normal subjects. Clin. Sci. $1965,28,357$.

7. Nordmann, J., and R. Nordmann. Organic acids in blood and urine in Advances in Clinical Chemistry, H. Sobotka and C. P. Steward, Eds. New York, Academic Press, 1961, vol. 4, p. 67. 